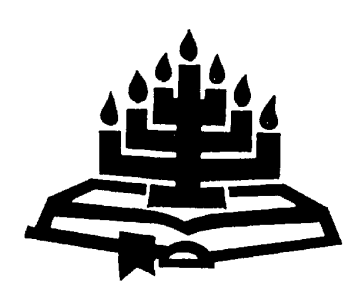

\title{
Tyd in die slot van die boek Amos
}

\author{
J.L. Helberg \\ Skool vir Bybelwetenskappe en Bybeltale \\ Potchefstroomse Universiteit vir CHO \\ POTCHEFSTROOM
}

\begin{abstract}
Time in the epilogue of the book of Amos

This article examines the concept of time, as filled with action, and as used in the epilogue of Amos. The concept of time is scrutinized in the light of the surprising announcement of prosperity and peace over and against the announcement of ruin in the rest of the book. The issue is approached against the background of Amos' integrative as well as transcending (and eschatological) perspective. Viewed cyclically and mythologically, Israel integrated all things in the cult by trying to manipulate time and even God. In reality time and history were frozen in the Israelite way of thinking. This mode of thinking caused the disintegration of the cult from everyday life and from God who reveals Himself as personal and thus requiring sound personal relations between himself and His people. Amos calls for genuine integration in all respects. The epilogue leads this integration to a climax making use of the idea that Yahweh is the all-powerfull and life-creating God, an idea which runs like a golden thread through the Old Testament.
\end{abstract}

\section{Inleiding}

Dit gaan in hierdie artikel nie om tyd as sodanig nie, maar om tyd konkreet gesien, gevul met gebeurtenisse, soos byvoorbeeld in die begrip "dag van Jahwe" (vgl. Jenni, 1976:379-385 vir die begrip tyd in die Ou Testament). ${ }^{1}$ Israel het verwag dat 'n dag van Jahwe sal aanbreek wat vir hulle redding en vir die vyande vernietigende straf sal bring. Die boek Amos trek saam in 'n ontnugterende aankondiging van dié dag en dus van hierdie tydsbenadering van Israel. Dié dag neem enersyds kosmologiese afmetings aan (5:8-9) en word andersyds histories

1 Die situering van tekste en hoe hulle in tyd van mekaar verwyder is, kan meer bydra tot die verstaan van tyd as leksikale en sintaktiese middels. Vergelyk ook Olivier (1996:257) dat die kombinering van die verstaan van ruimte en van tyd nodig is om die mens te verstaan. 
aan Israel voltrek deurdat hulle in ballingskap weggevoer sal word (5:18-20). Die dag van Jahwe is vernietigend en het ' $n$ totale en finale aard.

Tog, net so onverwags verkondig die slot 'n tyd van onversteurbare en voortdurende voorspoed, oorvloed en vrede met God: "Daardie dag bou Ek die vervalle hut van Dawid weer op" (9:11) en "Daar kom 'n tyd, sê Jahwe, dat daar direk na die oes geploeg sal word ..." (9:13).

Hoe hou hierdie positiewe slot van Amos verband met die finale ondergangsaankondiging vir Israel en hoe kom dit uit hierdie afgrond uit? Is die slot 'n redaktor of redaktore se benadering, (bloot) gebore uit 'n situasie ná ondergang, ná die ballingskap? ${ }^{2}$ Is daar in die slot se benadering van tyd iets wat lig op die saak werp? Is daar 'n eenheid tussen die slot en die res?

Hierdie artikel wil kyk na wat Israel volgens Amos van tyd maak, in sover dit ons onderwerp raak, en hoe die slot van die boek Amos daarop reageer. 'n Oplossing word gesoek in Amos se integrerende benadering, gepaard met die benadering van Jahwe as persoonlike en lewewekkende God. Daarvoor sal die volgende aspekte behandel word: die Ou-Testamentiese (historiese) tydsbenadering; Israel se tydsbenadering in die tyd van Amos; die tydsbenadering van die profeet Amos; die tydsbenadering in die slot van die boek Amos; samevatting en gevolgtrekking. Hierdie aspek kan nie waterdig van mekaar geskei word nie, maar sal in die onderskeie onderafdelings tersaaklike toespitsing ontvang.

\section{Die Ou-Testamentiese (historiese) tydsbenadering}

Hier word slegs die aspekte bespreek wat vir ons onderwerp in Amos van direkte belang is. In die eerste paragrawe word sterk angesluit by Saebo (1980:580$585)$.

God is die Here van dag en tyd aangesien Hy die Skepper van lig en duisternis en van dag en jaargetye is (Ps. 74:16-17; 139:11-12; Jes. 45:7; Jer. 33:20; vgl. ook Am. 5:8; 8:2-3, 9). As verwysing na die son- of liggedeelte beklee dag 'n voorrang bo nag. Die vaste afwisseling van dag en nag as skeppingsordening is teologies van deurslaggewende belang. Hierdie afwisseling is ná die sondvloed bestendig (Gen. 8:22; Jer. 33:20; vgl. ook die slot van Amos) en sal eers eskatologies in die heerlike eindopenbaring van Jahwe opgehef wees (Sag. 14:7). Dit beteken egter nie dat die Ou-Testamentiese godsdiens vasgevang was in 'n sikliese benadering van jaargetye, die natuur, tyd en die lewe in die algemeen nie.

2 Die meeste Ou-Testamentici beskou die slot as van ballingskapse of na-ballingskapse oorsprong. Vergelyk vir 'n nadere bespreking van hierdie problematiek en die tersaaklike literatuur daaroor, Helberg (1997). Vergelyk verder Firth (1996:372-382) volgens wie 9:11-15 op twee vlakke werk, naamlik 'n mondelinge vlak wat straf verkondig aan die Tienstammeryk, en 'n literêre vlak wat 'n belofte vir die suidelike ryk verkondig en wat van redaktors afkomstig is. 
Daar was 'n sterk historiese besef en natuurgebeurtenisse is sterk aan die seën van Jahwe verbind (vgl. veral Westermann, 1978:7, 72-101).

Die kategorie van tyd het voorrang bo dié van plek. Die skepping begin nie met die skeiding van ruimte nie, maar met die skeiding van dag en nag as fundamentele ordening van tyd (Westermann, 1974:157). Daardeur is ook die moontlikheid geskep vir die sewe-dae-skema sowel as sy verbinding met die geskiedenis (vgl. Westermann, 1974:155; vgl. die bespreking oor Amos se aansluiting by die Sabbat hier onder).

In die benadering en berekening van dag en tyd in die algemeen moet daar ook rekening gehou word met ' $n$ spanning tussen lig en donker in die Ou Testament. Vir ons doel kan veral verwys word na Amos se verbinding van Jahwe se optrede met lig $(4: 13 ; 5: 8)$, Jahwe se heerskappy oor hemelliggame en sy vernietiging van magte (5:8-9) en die feit dat die dag van Jahwe vir Israel donker bring en nie lig nie (5:18-20). Sedert die ballingskap en die gepaardgaande ondergang van die tempelstad Jerusalem word daar ook teruggekyk op die dag van Jahwe as dié dag van God se toorn en as iets wat reeds aangebreek het (Klaagl. 1:12; 2:1, 21). Tog is dié dag nog steeds in vooruitsig gestel. Die eindstadium word bereik met die apokaliptiek van Daniël waar die dag van Jahwe plek gemaak het vir, onder andere, (einde) (Von Rad, 1978:946-947).

Die gebeurteniskarakter van die dag van Jahwe en ander karakteriserings van dié dag het steeds sterker op die voorgrond getree, maar die tydkarakter het tog bewaar gebly. Amos hanteer hierdie aspek in die lig van Israel se mitologiese benadering onder invloed van hulle bure wat sterk siklies gedink het.

Die dag van Jahwe gee uitdrukking aan die sterk teosentriese benadering van die profete: God behou die inisiatief tot magtige dade en oefen heerskappy uit oor tyd en die "geskiedenis" van die volk Israel en die volke. Die dag van Jahwe het 'n ambivalente karakter gehad. Dit het onheil gebring vir die vyande van Jahwe en heil vir dié wat aan Hom behoort. Hierdie ambivalensie het die oorgang van voorstelling uit die onheilsprofesie na die heilsprofesie moontlik gemaak (Jenni, 1971:726) en kon 'n rol gespeel het in die onverwagte heilsaankondiging in die slot van Amos. Dieselfde geld vir die feit van die almag van Jahwe en die sonde van Israel wat albei saam in die Ou Testament benadruk word en dikwels aanleiding gee tot die paradoks waarin hopeloosheid en hoop, lig en duisternis ongeskeie inmekaar lê (vgl. Tsevat, 1982:938).

Dit gaan vir Israel en vir die Ou Testament nie om tyd in abstrakte sin nie, ook nie om mitologiese tyd nie, maar om die tyd van gebeurtenisse - anders gestel: om geskiedenis. Mite daarenteen kan soos volg omskryf word: dit probeer om ruimtelike werklikheid te verstaan in terme van die huidige wêreldorde, gesien as iets wat besig is om in 'n voor-historiese handeling te gebeur en die wêreld van 
nie-bestaan te bowe kom. Die werklikheid word gesien as staties, onveranderlik, fluktuerend in 'n ritmiese patroon, maar altyd met die doel om na die verlede toe terug te keer (vgl. Brinkman, 1992:48; Heyns, 1995:349, 351). Die Ou Testament daarenteen verstaan die werklikheid in terme van 'n nuwe skepping wat nóg in terme van die huidige wêreldorde nóg in terme van die wêreld van nie-bestaan geïdentifiseer moet word. God is in die geskiedenis besig om 'n nuwe ruimtelike werklikheid analoog aan die temporele werklikheid te bewerk, nie geskei van die huidige werklikheid van ruimte nie, maar verskillend in kwaliteit. Jahwe se tyd is inklusief; dit sluit mitiese, sikliese tyd sowel as historiese, liniêre tyd in (Heyns, 1995:352). Die Ou-Testamentiese verstaan van ruimte is eskatologies; dit kyk nie na die verlede toe nie, maar na die toekoms toe. In hierdie verband moet bygevoeg word dat die Ou Testament wel baie dikwels na die uittog uit Egipte verwys, maar dat die fokus ook daar eerder op die toekoms gerig is (vgl. die bespreking hier onder oor die verwysing na die uittog van die nasies in 9:7).

Geskiedenis het ' $\mathrm{n}$ baie belangrike plek in die Ou Testament. Von Rad (1962: 121-122) beweer selfs dat Deuteronomium 26:5-9 'n konfessionele opsomming van die heilsgeskiedenis gee. Hierteen is tereg beswaar ingebring (vgl. byvoorbeeld Vriezen, 1963:5-17). Dit verminder egter nie die belangrikheid van die historiese aard van die Ou Testament wat deur Von Rad weer sterk op die voorgrond gestel is nie.

Volgens Snaith (1963:175-186) kom "sikliese tyd", "horisontale tyd" en "vertikale tyd" in die Ou Testament voor. By "sikliese tyd" word sterk gedink in terme van 'n gedurige herhaling van gebeurtenisse en by "horisontale tyd" in terme van gebeurtenisse wat horisontaal na 'n doelpunt beweeg. Vir Snaith is "vertikale tyd", waarin gewone tyd getransendeer word, die spesifieke Hebreeuse bydrae tot tydsbesef. Snaith oorbeklemtoon hierdie aspek, sodat "geskiedenis", wat tog horisontaal na 'n doelpunt toe beweeg, in gedrang kom, maar die belangrike betekenis van tyd in die Ou Testament word ook deur hom duidelik na vore gebring.

Die religie van Israel word selfs ' $n$ religie van tyd genoem wat beoog om tyd te heilig; vandaar ook die belangrike plek van die Sabbat, wat in die nouste verband met die hele lewe staan. Die priesterlike benadering stel belang in orde, in ooreenstemming met die feit dat God 'n geordende wêreld geskep het. Aan die hart van daardie orde is 'n rituele orde. Hierdie orde word gedurig bedreig, veral deur sonde en verontreiniging. Die geskape orde moet dus in stand gehou word. Hiervoor is veral die verdelings en skeidings in ruimte, tyd en status nodig (status van te voldoen aan die gestelde vereistes; vgl. Brinkman, 1992:22).

Weens die sterk historiese inslag van die Ou Testament word die verbond en verkiesing nie abstrak, tydloos benader, in isolasie van 'n mens se verantwoordelikheid en bereidheid tot diensbaarheid nie (Eks. 19:5-6; Am 3:2; vgl. ook 
Preuss, 1991:40 wat daarop wys dat verkiesing nie 'n bo-tydelike raadsbesluit van God is nie, maar nou saamhang met belofte, wat op vervulling wag en hoop oproep). Verder word selfs die Tora of gebooie met 'n historiese inleiding begin: "Ek is die Here jou God wat jou uit Egipte uit die plek van slawerny bevry het" (Eks. 20:2; Deut. 5:6). Die feit dat Deuteronomium 5 die historiese gebeurtenis van Israel se verlossing uit Egipte as rede aangee dat hulle die Sabbat moet onderhou, in onderskeiding van Eksodus 20 wat God se optrede by die skepping as rede gee, is ' $\mathrm{n}$ verdere bewys van watter belangrike betekenis die $\mathrm{Ou}$ Testament nie slegs aan skepping nie, maar ook aan geskiedenis toeken. In ooreenstemming hiermee word die gebooie nie uitgeput deur die letter daarvan na te kom nie, maar beslaan hulle die hele lewe en het hulle met gesindheid te doen. Historiese situasies moet daarvolgens gehanteer word (vgl. die eis om liefde vir die vreemdeling in Levitikus 19 en die feit dat vreemdelinge in die nuwe situasie wat Esegiël 47 in vooruitsig stel, selfs besitreg op grond sal kan hê). Jahwe het konkreet histories vir Israel opgetree; daarom moet hulle konkreet histories teenoor hulle naaste optree.

Geskiedenis beteken vir die Ou Testament nie stolling in die verlede nie, maar die deurbreking van die sikliese lewensgang en lewensbenadering wat alles dieselfde wil hou. Laasgenoemde benadering streef balans na in plaas daaarvan om op te roep tot deurbreking, verandering, bekering soos die Ou Testament eis. Talmon (1986:37) wys daarop dat Bybelse hoop vir die toekoms sterk verbind is met die verlede; daarom het die koningskap 'n pilaar gevorm in die toekomsverwagtings. Hierdie hoop was nie toegespits op 'n beeld van 'n unieke messias nie, maar is lewendig gehou deur 'n visie van 'n dinastie van gesalfde konings. Hierdie opvatting het sy volste uitdrukking gevind in die profetiese visie van die laaste dae

. Die meeste voorstellings hiervan is ontleen aan die historiese ervaring in die nasionale lewe, in besonder van die glorieryke tyd van Dawid en Salomo. Toe is Israel se begeerte verwerklik om as nasie in sy eie land te woon, geborge en voorspoedig soos nooit anders in sy geskiedenis nie.

Volgens die Ou Testament is dit Gód wat plek en tyd saambind, soos gesien by sy skeppingsoptrede (Gen. 1). Die skeppingswerk trek saam in die mens as beeld van God (1:26-27). Ook die mens word dus teosentries benader. Ná die skepping van die mens as kroon van die hele skepping op die sesde dag, rus God op die sewende dag. Daarom moet die mens op hierdie dag self rus (Eks. 20:8-11). Die $ת>\Omega$ of geskiedenis van hemel en aarde (Gen. 2:4) is ten nouste verbind met mense en wat van hulle geword het (vgl. die $\Omega \quad \Omega$ van Adam in Gen. 5:1 en daarna telkens in verband met die aartsvaders). Iemand se $\Omega \quad \neg$ handel veral oor wat van die volgende persoon of persone geword het (Holwerda, 1971:9-17; Childs, 1979:145-150). Hier is dus 'n soort teleskopering (vgl. onder), verbind met vooruitskouing. 
Hoofmomente van die openbaringsgeskiedenis het met tyd te doen en is met God se lewewekkende optrede verbind. Behalwe by die skepping word dit gevind waar Hy 'n nuwe begin uit 'n ondergangsituasie bewerk, soos in geslagsregisters, die sondvloed, die roeping van Abraham en van Moses en by die konings, soos die bespreking in die volgende paragrawe sal wys. Ondanks die vervulling van die doodsdreiging in die tuin van Eden gaan die geslagte voort. Hierdie voortgang word aangedui deur die geslagsregisters en veral die feit dat Henog van die dood uitgesonder word (Gen. 5). Die sondvloed bring ondergang maar word tog opgevolg met 'n vaste orde van die seisoene (Gen. 8:22) en 'n belofte van God. Ondanks die mens se totale korruptheid wat die ondergang verdien (Gen. 6:6-7), sal God die aarde nie weer met water laat vergaan nie (Gen. 8:21).

Wanneer die nasies se tyd-/geslagsregister afgesny word, begin God met 'n nuwe geslagsregister, naamlik dié van Sem. Hierdie geslagsregister word self ook gekenmerk deur voortgesette lewensverkorting en loop dood, want dit eindig met 'n kinderlose egpaar (Gen. 11:10-32). Abraham ontvang egter 'n belofte dat hy 'n nageslag sal hê - lewe word uit die dood verwek. Tegelykertyd word daar ook voortgang, seën deur Abraham vir die nasies in vooruitsig gestel (Gen. 12:1-3).

Israel se tyd word deur die onderdrukking onder die Egiptenaars prakties afgesny en hulle word aan die dood prysgegee. God gryp egter in deur Moses en bewerk wonderbaarlike redding (Eks. 1:8, 22; 2:23-25). Dieselfde soort voortgang uit ondergang sien ons by die konings. Israel se tyd is prakties beëindig deur die Filistynse bedreiging, maar Jahwe maak 'n nuwe begin met Samuel wat die eerste koning instel. Hierdie begin loop uit op Dawid met wie Jahwe 'n "ewige" verbond sluit.

In plaas van in dit alles God se lewewekkende optrede te herken wat hulle tot ootmoed, dankbaarheid en bekering stem, het Israel die verkeerde afleiding gemaak dat daar niks is wat hulle verhouding met God en hulle voortbestaan in die weg kan staan nie. Hulle het vasgedraai en gestol in 'n outomatiese versekering van hulle redding, voortbestaan en bevoorregte verhouding met God.

\section{Israel se tydsbenadering in die tyd van Amos}

Israel het die dag van Jahwe verwag as 'n tyd wat sonder meer vir hulle voorspoed sou bring. In hierdie benadering was hulle beïnvloed deur hulle tydgenote se mitologiese tydsbenadering.

Tyd (gesien as gevul met gebeurtenisse, seën, voorspoed, ens.) kan volgens hulle benadering beïnvloed, gestimuleer, bepaal of selfs gemanipuleer word deur seremoniële handelinge, uitgevoer in die amptelike kultus, veral tydens samekomste en feeste. Anders as by 'n ware verdeling of onderskeiding van ruimte, tyd en status (vgl. bo), het Israel in die tyd van Amos nie 'n oop oog gehad vir 
sonde en verontreiniging nie, in elk geval nie in religieus-etiese sin nie. Hulle godsdiens het opgegaan in seremoniële reiniging en 'n geïsoleerde tyd vir sulke seremonies. Godsdiens was vir hulle nie iets wat die hele lewe en al die tyd moet deursuur nie.

Hulle het die Sabbat as iets op sigself gesien, 'n dag vir kultiese en seremoniële handelinge, wat los staan van die daaglikse doen en late, 'n tyd wat hulle omgewens het om weer met hulle eie sake voort te gaan volgens hulle eie selfsugtige oogmerke (8:5-6). In plaas van 'n religieus-eties gefundeerde status het finansiële en magstatus by Israel gegeld. Hierdie nie-religieus-etiese status het oral geseëvier: in die daaglikse lewe, in die handel en selfs by die heiligdom (3:6$8 ; 8: 4-6)$. Dit was in werklikheid teen-relieus-eties en vir God tot 'n aanstoot. Dit het hulle geleer om kwaad te doen (5:4-5), nie om goed te doen nie (5:14). Hulle moes daarom 'n ander soort godsdiensbeoefening soek deur na die wil van Jahwe te vra en reg te laat geskied $(5: 4,6-7,15,21-24)$.

Heyns (1997b:239) wys daarop dat die tekening van die herfsfees in Amos (8:1) die landboujaar nie alleen tot sy kulminasie en einde bring nie, maar ook tot die krisis van oorgang. Volgens die vrugbaarheidskultusse moes die ritme van tyd ritueel hernuwe word sodat die seisoensiklus in die nuwe jaar kon voortduur. Die fees aan die einde van die somer (in Israel) was toegespits op tyd wat na sy einde beweeg en daarom was die ritueel van die fees 'n rite van verbygaan of oorbrugging (vgl. ook Deist \& Le Roux, 1987:58-59). Die gedagte dat Jahwe aan Israel die land gegee het, was verbind met die gedagte dat $\mathrm{Hy}$ ook die vrugbaarheid bepaal en beheer oor die kosmiese magte uitoefen. Israel het wel die feesrituele onderhou, maar het tyd misbruik en God sodoende aangedurf, sy heerskappy betwis en hulle grense oorskrei. So het hulle die skeppingsorde versteur.

In 'n ander insiggewende artikel wys Heyns (1997a:34) dat die veiligheid en heiligheid van Israel as volk in die verbondsverhouding met Jahwe lê. Die stadsmuur in die visioen van die skietlood (7:7-9) is ook 'n simbool van hierdie verbondsverhouding wat hulle leefruimte omsluit en geheilig het en daarmee kosmiese beskerming verleen het. Die visioen van die skietlood hou verband met die waarneming van hemelliggame en die daarmee samehangende voorspelling van tyd en gebeurtenisse. Om die hemel te bespied en tye te bereken het die mag van die tempel en priesters versterk deurdat hulle aan die volk veiligheid en beskerming teen die onbekende verskaf. Israel het egter van die huis van God (Gen. 28) die "huis (tempel) van die koning" gemaak (7:10-17). Verbondsruimte het kultiese ruimte geword; verbondsbelofte van die land, kultiese veiligheid/ sekerheid (Heyns, 1997a:36). Ons kan hier nog byvoeg: uittog het selfgesentreerdheid geword (kontra Lev. 19:33-34; Deut. 5:14-15 - vierde gebod); verkiesing het bevoorregting, sonder verantwoordelikheid geword (Am. 3:2); die dag van Jahwe het valse sekerheid geword (5:18). 
Volgens Amos se vierde en vyfde visioen sal die priester egter nie meer in staat wees om die tyd van die kalender en feeste te bepaal nie, want Jahwe beheer die tye en geskiedenis van Israel en die kosmiese magte van die natuur. Hy sal kultiese tyd laat ophou; die muur sal nie langer die sentrum van koninklike mag bepaal nie. Heilige ruimte sal oopgegooi word vir die chaosmagte en die ekologiese katastrofe sal tyd omsluit. God kan sy skepping skep óf in trurat plaas, Hy kan teruggaan of vorentoe gaan in tyd, Hy kan dit laat terugkeer of nie terugkeer nie (vgl.

in 1:3-2:6; Heyns, 1997a:37). Heyns sê tereg dat die natuur en geskiedenis skarnier op Jahwe se potensiaal om alle moontlikhede te beheer. Die vraag wat hierdeur vir die doel van ons artikel opgeroep word, is hoe Hy dit doen. Die persoonlike (verbonds)verhouding bly juis van Israel se kant in die slag. Die antwoord wat die slot van Amos verskaf, is dat Hy dit self, op eie inisiatief, herstel ("Hy sal dit doen”, 9:12; vgl. die bespreking onder).

\section{Die tydsbenadering van die profeet Amos}

Amos sluit sterk aan by die Ou Testament se historiese en veral persoonlike benadering. Hy lê baie sterk nadruk op sy roeping deur Jahwe persoonlik. Sy roeping het plaasgevind agter die skape waar hy met sy daaglikse werk besig was (7:14-15). Die inhoud van sy verkondiging is daarom ook toegespits op die daaglikse gang van die lewe in Israel. 'n Ware verhouding met God, met ander woorde ware godsdiens, vra integrering met die volle lewe en alle verhoudinge en ten alle tye.

Volgens Amos het Israel hulle tyd verspeel en selfs misbruik. Hulle het selfs onreg bedink terwyl hulle met die viering van heilige tyd (Sabbat) besig was (2:8; 8:5-6). Daarom word hulle plek (land) hulle ontneem (vgl. die bespreking van die voorrang van tyd bo die kategorie van plek). Die ergste is dat hulle verhouding (met Jahwe) daarmee heen is - eintlik het hulle lankal daardie verhouding verspeel. Dit is juis hierdie verhouding wat die ware voorrang het, soos ook blyk uit die tuin-geskiedenis. Herstel lê alleen in die herstel van dié verhouding. Amos maak op 'n ironiese manier gebruik van Israel se eie opvattings om hulle tot ander insigte te bring. Die dag van Jahwe sal inderdaad kom soos hulle verwag, maar dit sal nie lig, redding, vreugde bring nie, maar donkerheid $(5: 18-20)$. Dit is omdat Israel nie na die wil van Jahwe vra nie, maar na dié van hulle eiewillige kultus by Bet-El, Gilgal en Berseba (5:4-6) waar sinkretistiese invloede hulle laat geld het.

Soos uit die verband blyk, steun Israel op hemelliggame vir aanduidings van tyd en gebeurtenisse (5:8). Dit is 'n godsdiensbeoefening sonder verband met die praktiese lewe, sonder geregtigheid (5:7), sonder besef wie werklik beheer oor die daaglikse gang van die natuur, reën en vrugbaarheid het (5:8) en die gang van gebeurtenisse in verband met mense bepaal (5:9). Israel vra tydsaanduidings vol geheimsinnige, mitologiese betekenis, in plaas van tyd te vul met geregtigheid 
(5:10-12). Daarom is dit ' $n$ bose tyd (5:13). Amos beantwoord hierdie geheimsinnigheid en gepaardgaande gebrek aan geregtigheid deur Jahwe se ontferming ook geheimsinnig te stel: "dalk" sal Jahwe Hom ontferm (9:15).

Israel het die Pasgafees en dus die Pasgatyd gemitologiseer asof dit iets sou wees waarmee hulle jaarliks as't ware die gebeurtenis van die uittog simuleer en herhaal sodat daar outomatiese redding geskenk word. Maar hulle sal op dié dag treur, nie jubel nie, sê Amos $(5: 16,17)$. Die gebeurtenis van die uittog toe die Here by sy volk verbygegaan het en net die Egiptenaars met sy vernietigende straf getref het (Pasga, Eks. 12:23), is deur Israel gemitologiseer tot 'n tydlose, ewigdurende waarborg van Jahwe se redding vir Israel. Amos "historiseer" hierdie mitologiese benadering. Hy maak 'n sinspeling op die uittog, maar doen dit op ' $n$ ironiese manier en sê dat Jahwe tussen hulle sal deurgaan om hulle te straf (5:17). Die teenoorgestelde van wat Israel verwag, gaan in der waarheid aanbreek. Die vernietiging van die nasies wat Israel in vooruitsig gestel het, gaan oor Israel self losbars $(5: 18-20 ; 8: 7-1,11-14 ; 9: 5-6)$. Die dag van Jahwe is 'n dag van geregtigheid, nie 'n dag van wraak vir Israel oor hulle vyande nie. Wie nie die toets van geregtigheid kan deurstaan nie, is aan die verkeerde kant van die dag van Jahwe. Jahwe en sy wyse en tyd van optrede kan deur niks gemanipuleer word nie.

Jahwe put nie vreugde uit Israel se kultus met feeste, offers en musiek nie, maar haat dit (5:21-23). Die woestynreis ná die uittog uit Egipte is 'n bewys dat dit vir Jahwe nie gaan om kultus en seremoniële dinge, waarin die tyd as't ware vasgevang en gemanipuleer word nie. Dit gaan om Jahwe se eie persoonlike en vrymagtige optrede. Hy is vir sy optrede nie van hierdie soort handelinge en veral nie van Israel se versorging afhanklik nie, maar is selfgenoegsaam. Hy het nie offerandes van Israel gevra nie, maar het hulle versorg in 'n tyd toe hulle nie eens genoeg gehad het om hulleself te versorg nie (5:25).

Nou vertrou hulle soos die heidene op hemelliggame wat die tyd met sy gebeurtenis sou bepaal. Van dié hemelligame maak hulle gode, maar dié is net so sorgbehoewend soos hulleself (5:26). In plaas daarvan om vir Israel te sorg, moet hulle deur Israel versorg word. Amos teken die situasie fyn: hierdie gode sal in Jahwe se straffende optrede deur Israel gedra word in ballingskap en ondergang in! (5:27). Israel word afgesny van hulle land, hulle bestaansruimte en van God se beloftes waarin die land so 'n belangrike plek het. Hulle tyd is uitgeloop. Om hulle land te verloor, beteken om hulle geskiedenis met Jahwe te verloor. Volgens die chronologie van hulle koning in Jerusalem is Israel se geskiedenis ingevoeg in wêreldtyd, maar in die ballingskap is hulle ingevoeg in wêreldtyd deur die chronologie van die Babiloniese heersers wie se tyd deur die sterre bepaal is (Heyns, 1995:352). 
Israel wil deur die kultus die tyd manipuleer en sodoende die nuwe jaar se vrugbaarheid en voorspoed verseker. So iets lê egter buite die mens se vermoë. Israel se sekerheid lê in 'n verbondsverhouding met Jahwe, maar nie 'n onpersoonlike, meganiese verhouding wat deur seremoniële pligpleginge bewerkstellig word nie. Amos vermy die woord "verbond", blykbaar juis omrede die wanopvatting wat Israel oor die verbondsverhouding gehad het. Anders as die ander gode is Jahwe immers die Skepper en nie 'n deel van die natuurverskynsels of natuurkragte nie (5:25-26). Straf word herroep as daar op God se ontferming gepleit word - nie as dit op grond van vermeende verbondsregte geëis word nie (7:1-6).

Israel maak die Woord van Jahwe stil, sê Amos. Israel belet die profete om hulle verkondiging te doen. Dat Jahwe Hom laat stil maak, is ironies. Hy is immers in volle beheer. Hy sal 'n honger oor die aarde laat kom, 'n honger nie na kos nie, maar om die woorde van Jahwe te hoor. Hierdie honger sal egter tevergeefs wees (8:11-14). Nóg tyd nóg Jahwe kan gemanipuleer word. Jahwe gee tyd en geleenthede, maar as dit nie gebruik word nie, kan die tyd onherroeplik verbygaan. As persoonlike God is Jahwe immers 'n morele God, wat moraliteit en bekering eis, veral by sy volk (vgl. die refrein in 4:6-11; 5:14-15; 18-26). Amos verwag ook heiliging by Israel soos in die boek Levitikus gestel, maar in ooreenstemming met sy sterk religieus-etiese beklemtoning gebruik hy nie die woord daarvoor nie. word twee keer in Amos gebruik, en wel in verband met Jahwe (4:2) en sy Naam (2:7). Albei kere het dit direkte verband met Israel se veronregting van hulpeloses - nie met die kultus nie.

Levitikus 19 word beheers deur die uitdrukking: "Ek is Jahwe julle God". Jahwe is heilig en daarom moet sy volk ook heilig wees (19:2). Hierdie aspek van heilig wees moet uitkom in die betoning van reg teenoor die naaste, in besonder die swakkes en vreemdelinge (19:13-14). Israel moet hulle naaste liefhê soos hulleself (19:18). Die feit dat Jahwe Israel uit Egipte en uit hulle vreemdelingskap gelei het, vereis dat hulle sy gebooie moet onderhou en vreemdelinge moet liefhê (19:33-36). Volgens Levitikus is die volgende dus ten nouste aan mekaar verbind: 'n (verbonds)verhouding met Jahwe, geregtigheid teenoor die naaste (insluitende vreemdelinge/nasies), onderhouding van die gebooie, en liefde. Dieselfde geld vir die verkondiging van Amos.

Terwyl Israel onder invloed van hulle tydgenote tyd mitologies benader, benader die $\mathrm{Ou}$ Testament tyd histories. As deel van die historiese aspek benadruk Amos wat Israel uit die oog verloor het. Hy benader tyd "teologies-eties". Tyd is vir hom 'n geleentheid vir diens, vir die beoefening van geregtigheid (vgl. die kwessie van Sabbat, handel, kullery, hardvogtigheid, 8:5-6), maar daarom as iets wat finaliteit het. Tyd hou volgens Amos vir Israel iets finaal straffends in omrede hulle totale gebrek aan geregtigheid en hulle hardkoppige volharding (5:7-17) daarin. Hulle ongelooflike selfsug en ongeregtigheid het skrikwekkende gevolge, 
insluitende die dag van Jahwe as 'n dag van duisternis (5:18-20), en 'n verterende honger na die Woord (8:7-14). Die mens kan van brood alleen nie leef nie, maar van die Woord wat sinvolle lewe en laat lewe moontlik maak. Israel sal losgeruk word van plek/land en van tyd, soos van die ware Pasga wat herinner aan Jahwe se reddende optrede en beloftes en wat daarom vooruitsig insluit, soos op die reddende dag van Jahwe. Israel het geskiedenis, tyd, laat stol in mitologie. Deur hierdie gestoldheid is hulle in hulle volle bestaan gestol en dus dood. Jahwe laat hulle geskiedenis stol in die dag van Jahwe, in ballingskap (5:27). Dit is ondergang waaruit geen uitkoms moontlik is nie. Alleen 'n regte sig op tyd/geskiedenis - nee op God wat persoonlik alles beheer, ook die tyd - bring lewe in sy volheid.

Jahwe is vir Amos die lewewekkende God, wat donker in oggendlig verander (4:13) en wat die water van die see roep en dit oor die aarde uitstort (5:8). Hy kan uit ondergang voortgang te voorskyn bring, maar Hy kan ook ondergang bewerk. Die beheersende hoedanigheid van Jahwe in Amos (behalwe in die slot) is wel bedreiging: reeds die inleiding sê dat Hy weivelde laat verdor (1:2). Verder laat Jahwe die dag donker nag word (vir laasgenoemde vgl. ook 4:13). Hy is die God wat die magtige (vgl. 6:13) met vernietiging tref (5:9). Tog is Hy andersyds die God wat die lot van mense in 'n situasie van ondergang ter harte neem, soos dié van armes en verdruktes.

Vir ons doel kom die vraag na vore: Wat van Israel wat in 'n ondergangsituasie is? Hierop gee die slot antwoord. God bly nog steeds die God wat ondergang kan bewerk en wat ook lewe uit ondergang of dood kan wek.

In die apokaliptiese gedeelte van Daniël is deur (einde) en ander vaste terme verdring (Preuss, 1991:584). Op die oog af verkondig ook Amos so 'n einde, soos blyk uit die gesig van die mandjie met somervrugte en die woordspeling $\quad-\quad$ : somer - einde (8:2; vgl. ook 5:18-20; 9:1-4). Daar is geen ontvlugting nie, nie in die doderyk daar onder of in die hemel daarbo, nie op die bodem van die see of ver weg in die land van ballingskap nie. Israel kan op geen manier God in sy toorn ontvlug nie. Alles trek daarin saam dat hierdie verhouding met God persoonlik versteur is (9:1-4). Die chaos slaan toe, sê Amos in ' $n$ ironiese hantering van Israel se benadering van die dag van Jahwe.

Soos die ironie impliseer, is dit egter tog anders; alles is onder beheer van Jahwe persoonlik. Die bedoeling is nie blote vernietiging, blote nie-bestaan, blote afsnyding van 'n mens se tyd nie, maar 'n situasie van straf. Dit gaan oor 'n aangetaste verhouding met God persoonlik en hierdie verhouding kan nie bloot beëindig word nie. Dit is dus 'n kwessie van óf voortdurende straf, óf versoening - dit wil sê as hierdie sikliese gang deurbreek sou kon word, waarvan hier (nog) niks in sig is nie. Amos 9:1-4 roep, deur die onontvlugbare straf heen, om herstel van die persoonlike verhouding met God. 
Amos wil Israel Jahwe laat ken as 'n God wat nie gemanipuleer kan word nie. Dit staan sentraal in die slot en die res van die boek. Dit sluit enige outomatisme uit, sowel heils- as onheilsoutomatisme - al is laasgenoemde implisiet.

\section{Die tydsbenadering in die slot van die boek Amos}

Die slot van Amos kom met 'n onverwagte aankondiging van redding, net so onverwags soos die aankondiging van die dag van Jahwe as dag van vernietigende straf in die voorafgaande gedeelte. Die blywende en gemeenskaplike faktore in albei gedeeltes is die Goddelike vrymag, onpeilbaarheid en onberekenbaarheid - in teenstelling tot 'n godsdiensbeoefening waarin Hy in sy optrede bereken word en selfs gemanipuleer word. In hierdie vrymag is sowel geregtigheid as herstel en voorspoed inbegrepe. Jahwe is meer as 'n mag of krag wat vir sy volk voorspoed bepaal deur onpersoonlike lotsbeslissings of manipulering in kultiese seremonies. Hy is 'n persoonlike God en vereis moraliteit. Hier het ons dus nog 'n gemeenskaplike faktor tussen die slot en die res van die boek. As persoonlike God is Jahwe ook nie 'n vernietigende God nie. Hy wil per slot van sake in 'n (verbonds)verhouding met mense staan: "Vra na my wil, dan sal julle lewe" (5:4).

Soos in die res van die boek Amos is tyd in die slot histories; nie mitologies, tydloos, sonder verband met die daaglikse lewe en optrede nie. Tyd het 'n verloop, is 'n proses waartydens Israel gesif sal word. Jahwe se koninkryk stel etiese eise en reken af met sondaars $(9: 8,10)$. Daar is perke aan sy toorn en straf, daarom roei Hy sy volk nie heeltemal uit nie (9:8; vgl. ook Ps. 103:8-19). Hy sal 'n oorblyfsel spaar, maar een wat vry is van selftevredenheid en valse gerustheid, vry van ' $n$ outomatiese benadering van redding. Redding word nie in 'n blote geïsoleerde kultiese atmosfeer uitgesorteer nie, maar in 'n historiese siftingsproses (9:9-10). Alles is wel deur en deur 'n kwessie van Goddelike optrede. Dáár lê die fokus in die slot; nie alleen in 9:11-15 nie, maar ook in 9:7-10. God se inisiatief en optrede is die bindingsfaktor van die boek as geheel.

Dit is Jahwe wat die tyd beheer; Hy lê die tydsiklusse vas én transendeer dit. Hy is meer as ' $n$ onpersoonlike bepalende mag; Hy is 'n persoonlike God met persoonlike deernis (7:1-6). Hy alleen, Skepper en almagtige God, kan uit Israel se finale ondergang iets te voorskyn laat kom. Hy sal dit doen deur die verhouding met Hom te herstel. Daarmee sal alle verhoudinge (met mense en die bodem) herstel wees, ook al word niks uitdrukliks gesê oor reg doen teenoor armes en onderdruktes nie. Ook in Genesis 1-3 staan die verhouding met God so voorop dat daar nie spesifiek oor die verhouding tussen mense gepraat word nie. (Laasgenoemde word wel histories na vore gebring in die onderlinge optrede van Adam en Eva, van Kaïn en Abel, van Lameg, ensovoorts.) Die versteurde verhouding met die bodem word wel spesifiek gestel, soos in Genesis 3 . 
Net soos in Genesis 3-11 word die lewewekkende optrede van God in die slot van Amos na vore gebring. Amos het met kreatiwiteit en ironie die tradisionele benaderings van Israel gehanteer, soos gesien in sy ontnugterende benadering van verkiesing (3:2), die uittog (9:7), die dag van Jahwe (5:18-20), die ryp vrugte en die einde van Israel $(8: 2)$ en die oorblyfsel wat ondergang vryspring $(3: 12 ; 9: 10)$. Die slot van die boek kom ook met 'n verrassende element, maar na die ander kant toe. Die res van die boek het gekonsentreer op die een been van die deurlopende gedagtelyn van God se lewewekkende werk in die Ou Testament, naamlik ondergang. Die slot bring die tweede been na vore: lewewekking uit die ondergang.

Die slot sluit aan by die ballingskap wat deur Amos in vooruitsig gestel is $(5: 18$; $7: 17 ; 9: 4)$ en verkondig dat Jahwe Israel weer in sy land sal plant. Verder sluit die slot aan by die standhoudende stroom van geregtigheid wat Jahwe deur die verkondiging van Amos vereis (5:24) en verkondig 'n standhoudende vloei van vrug uit die bodem (9:13). Maar dit is wat Jahwe self sal bewerk. Dat Israel geregtigheid sal beoefen, word glad nie gesê nie. Soos ná die sondvloed volg Jahwe 'n ander weg as bloot straf volgens verdienste. Hy bewerk 'n herstelde verhouding met en in die land, en hierdie verhouding rus in 'n herstelde, ware verhouding met Hom. Hy is die almagtige God, wat selfs teen sy eie volk kragdadig en selfs vernietigend optree $(3: 13 ; 4: 13 ; 5: 14-16,27 ; 6: 8,14 ; 9: 5)$. Maar Hy is tog nie 'n ondergangsgod nie, sê die slot.

Nie die tyd (of 'n tydgod) wat in kultiese seremonies gehanteer en gemanipuleer word, is bepalend vir wat gaan gebeur nie, maar die almagtige God wat in beheer is en aktief is. Hy is vrymagtig en kan nie voorgeskryf of ten volle gepeil word in wat Hy doen nie: nie in sy seënende optrede vir die komende seisoen nie en nie in sy historiese optrede, soos straffende optrede op die dag van Jahwe nie. Hy kan ook nie daarin gepeil of voorgeskryf word asof ballingskap en volksondergang die laaste woord is nie. Hy is soos Hy Hom aan Moses geopenbaar het as Jahwe, as Ek is wat Ek is (Eks. 3:14).

Amos benadruk dat Israel se lot nie abstrak, mitologies bepaal word nie, maar op die vlak van die persoonlike verhouding met God en die naaste, met ander woorde veral in die daaglikse verhoudinge. Die persoonlike verhouding is trouens benadruk deur die manier waarop Amos geroep is (7:7:14-15; vgl. ook Van Leeuwen, 1985:19) en bepaal die hele inhoud van sy verkondiging. Israel het egter in hierdie verhouding geheel en al misluk. Hulle het die verhouding met God wat die bron van die lewe is, in sy kern verbreek en daarom is ondergang onafwendbaar. Hulle optrede skrei teen die skeppingsdaad van God en teen Hom as Skepper (8:7-10; 9:5-6). In plaas daarvan om Hom te dien, dien Israel hulle eie selfgemaakte god (“jou god ...", Dan. 8:14). Om uit so 'n korrupte situasie, so 'n onherroeplike ondergang, iets tot stand te bring, vereis niks minder nie as 'n 
algehele nuwe begin, nuwe lewe uit dood. Dit is wat die uittog uit Egipte eintlik was en dit is wat Israel nou nodig het, maar Israel verstaan dit nie so nie.

So 'n moontlikheid lê in die hand van Jahwe alleen. Dit is Hy wat tyd beheers, uitgedruk in tipiese uitdrukkings soos "Daardie dag ..." (9:11), "Daar kom 'n tyd" (9:13; vgl. verder hierdie soort uitdrukkings by die profete. Vergelyk in hierdie verband Talmon, 1986:37). Dit is Hy wat die jaarsiklusse, nuwe seisoene, vrugbaarheid en voorspoed bepaal. Hy is die Skepper, wat getrou bly aan sy skepping, daarom ook aan sy volk Israel aan wie Hy hulle bestaan gegee het $(3: 2$; 9:15). Jahwe bly egter getrou volgens 'n ander perspektief as dié van Israel. Sy vrymag bly onaangetas en Hy kan nie 'n outomatiese God, tot diens van die mens en sy selfgesentreerde en selfsugtige wense, gemaak word nie (3:2; 9:7). Daar ís lewe ondanks die ondergangstraf. Dit kom as lewe uit die dood. Dit kom van die Almagtige God, die lewende God wat selfs optree wanneer daar menslik gesproke geen moontlikheid is nie, wanneer dit verby is met plek, tyd en status, insluitende verbondstatus en verkiesingstatus $(3: 2 ; 9: 7$; vgl. ook 6:7). Jahwe alleen, uit eie inisiatief, "Hy sal dit doen" (9:12). Hy sal die verhouding met Hom herstel ("my volk", "jou God", 9:15) en die vrug daarvan sal die situasie van voorspoed en vrede wees (9:13-15).

Die slot van Amos sluit aan by die sikliese benadering van voorspoed, wat deur Amos so fel beveg is. Maar die sikliese word tegelykertyd deurbreek. Daar kom 'n nuwe, lewewekkende begin: die vervalle hut van Dawid word weer opgerig. Dit is 'n nuwe situasie wat rus op en voortvloei uit 'n (herstelde) verhouding tussen Jahwe en Israel. In hierdie verhouding lê alles opgesluit (vgl. ook Kaiser, 1993:315 oor liefde as 'n plig en antwoord op die liefde wat Jahwe aan Israel betoon het, Deut. 7:6). Hiermee staan en val alles. As dít reg is, is geregtigheid vanselfsprekend en hoef dit nie eens genoem te word nie.

Dan is daar ' $n$ situasie soos deur Jeremia in vooruitsig gestel en ook ingelei met 'n formule soos "Daar kom 'n tyd" (Jer. 31:31). God se volk sal so 'n vrugdraende vergewing ontvang dat hulle nie meer aan hulle verpligtinge herinner sal hoef te word nie: "'n Man sal nie meer vir sy buurman of vir sy broer voorhou; 'jy moet die Here dien' nie, want almal sal My dien, klein en groot ... Ek sal hulle oortredings vergewe en nie meer aan hulle sondes dink nie" (Jer. 31:34). Ook die slot van Amos beloof so 'n vrugdraende vergewing wat dit onnodig sal maak om Israel te herinner om geregtigheid te beoefen. Dit sal wees soos die nuwe begin wat gemaak is met die ou korrupte mensdom ná die sondvloed (Gen. 8:21, 22). Hier is dieselfde soort onverwagte redding uit totale korruptheid en ondergang sowel as die belofte van 'n geordende natuur. In die slot van Amos is dit nog sterker geteken deur oorvloedige vrugbaarheid. Dan sal die spanning in die skepping opgehef wees. Die seisoene sal gereeld op mekaar volg, die vrug sal nie (deur vyande of kosmologiese steurnisse) van Israel weggeneem word nie en sal voorspoed en oorvloed bied. 
Israel sal bevry word uit ondergang, bevry van vreemdelingskap (die ballingskap); bevry uit die sikliese gang van goeie en slegte tye, van redding wat tog uiteindelik maar weer opgevolg word deur nuwe onheil wat toeslaan $(5: 11 ; 9: 14)$. Aan die grond hiervan lê om in God self versadig of bevredig te word. Dit gebeur deur sy Woord waarin sy wil uitgedruk is $(5: 4 ; 8: 11)$ en benadruk word deur die woorde waarmee die hele boek saamgevat en afgesluit word, naamlik: "sê Jahwe jou God". Hier is dus 'n geïntegreerdheid van gegewens soortgelyk aan die teleskopering van gegewens rondom 'n beperkte aantal plekke, datums en persone, soos in 2 Kronieke 3:1 waar die berg Moria in Jerusalem gelokaliseer word (vgl. Brinkman, 1992:253 oor Patte). Hierdie teleskopering pas ook heeltemal in by Amos se integrering van gawe en eis en van godsdiens en reg doen teenoor die naaste.

Die slot van Amos ontvlug dus nie die tyd, die werklikheid, die hede nie, maar bly histories gewortel: "Ek sal my volk weer in hulle grond plant" (9:15"). Tog word die tyd tegelykertyd deurbréék; die historiese word getransendeer deurdat bo-werklike voorspoed geteken word (9:13-14). Anders as in 'n sikliese benadering word 'n eskatologiese aspek aangeroer. Hede en toekoms word verbind op ' $n$ manier waarop albei se selfstandigheid gehandhaaf word maar die hede deur die toekoms in 'n ander perspektief geplaas word. So word daar plek gemaak vir verwagting, beloftes wat in vervulling sal gaan. Dit word steeds op 'n manier gedoen wat Israel se morele verantwoordelikheid hier en nou ten volle akkommodeer.

Die nuwe situasie kom onverwags en as 'n daad van God se ongemotiveerde, lewewekkende optrede. Tog is daar 'n brug tussen sonde en voorspoed. Genade is nie goedkoop, soos Israel gedink het nie, en kom nie sommer outomaties nie. Die morele element in die Ou-Testamentiese godsdiens word onverswak gehandhaaf. Straf is werklik, histories, selfs tot ondergang toe (9:8). Selfs die oorblyfsel wat gered word, is persone wat deur 'n (historiese, nie-mitologiese) proses van sifting (9:9) gaan en nie 'n outomatiese benadering oor oorblyfselwees het nie (9:10). Maar wat vas staan, is dat dit deur en deur God se wonderbaarlike reddende optrede is wat 'n nuwe begin kan maak. Hy bewerk durende voorspoed in 'n onverbreeklike verhouding met Hom.

So onverwags en teenoorgesteld aan die skynbare werklikheid as wat die dag van Jahwe teen Israel gaan losbreek (5:18), so onverwags en teen die skynbare werklikheid gaan daar vir Israel ware redding aanbreek $(9: 11,13)$. Ook hierin kom daar 'n belangrike wending: daar sal nie weer vir Israel 'n koninkryk soos vanouds wees nie. Die ou verhouding met die nasies sal deurbreek word en 'n universele ryk sal kom. Die beperkinge van die huidige bedeling in die natuur sal opgehef wees: daar sal direk na die oes geploeg word en direk na saaityd gepars word. Die berge sal van druiwesap drup en al die heuwels sal deurnat wees (9:13). 
Tyd word in die slot van Amos verbind met land, maar nie met stad nie. Hier word dieper getas as Israel en sy verkiesing (3:2) soos dit veral vergestalt was in die uittog uit Egipte $(2: 9-10 ; 9: 7)$. Die uittog was die groot en sentrale gebeurtenis in die bestaan van Israel en kan Israel se geboorte as volk genoem word. Hier in Amos word 'n nuwe begin in vooruitsig gestel, soos in die geskiedenis van Noag. Daar lei een en dieselfde motivering (algehele sondigheid van die mens, 6:6-7), onverwags en skynbaar onlogies, tot 'n teenoorgestelde konklusie: "Ek sal nie weer so 'n ramp oor die aarde laat kom vanweë die mens nie ... So lank as die aarde bly bestaan, sal saaityd en oestyd nie ophou nie, ook nie koue en hitte, somer en winter, dag en nag nie" (Gen. 8:21-22). In homself is die mens niks beter as tevore nie, maar tog bring God 'n ander oplossing. Ook in die slot van Amos is daar aan Israel se kant geen meriete vir verandering nie, maar bewerk God tog verandering. Nou geld dit ook nie meer net vir Israel nie, maar 'n deurbraak word na die nasies toe gemaak, net soos by die roeping van Abraham (Gen. 12:1-3).

Die slot van Amos pas dus nie in by wat Levenson (1985:88) as tipies van die naballingskapse benadering, met name die priesterlike, stel nie. Daarvolgens sou daar teenoor die dinamiese benadering van die profete wat beweging en verandering benadruk het, iets meer vas en staties benadruk gewees het, soos uitgedruk in die gedagte van rus in die Sabbat. In die slot van Amos is nie sprake van Sabbat of van rus nie, maar wel van vrug op die arbeid. Ná die oes word volgens hierdie voorstelling egter nie gerus nie, maar dadelik weer geploeg.

Daar sal 'n wees, nie iets staties nie, maar 'n vernuwing. Dit gaan nie om 'n bloot teruggekeerde situasie van die voortyd nie. In Klaagliedere 5:21 word en saam ter sprake gebring. Ook daar is Goddelike aksie en menslike reaksie as vrug daarvan ter sprake. Ook daar word nie 'n blote terugkeer na die situasie van die verlede geïmpliseer nie. Die vroeëre situasie was juis ook volgens Klaagliedere nie vir God aanvaarbaar nie, maar 'n grond vir die voltrekking van die dag van Jahwe aan Israel - 'n oordeel wat in ballingskap saamgetrek het (Klaagl. 1:1, 5, 12; 2:1). Die probleem was juis dat Israel gestol het in die verlede, soos vergestalt in die kultus. Amos het dit juis teen 'n gestolde godsdiens, een waarin daar 'n mitologiese verhouding met God is, in plaas van 'n lewende, persoonlike verhouding. Hierdie ware verhouding word in die slotwoorde na vore gebring. Die woorde "die land wat Ek hulle gegee het", impliseer Jahwe se historiese optrede, wat historiese reaksie vereis, reaksie in die daaglikse lewe. Die woorde "sê die Here jou God", benadruk die persoonlike verbondsverhouding.

Die tydsberekening van Israel is omver gegooi. Dit geld vir Jahwe se oordeelsoptrede soos in die res van die boek verkondig, én vir sy verlossende optrede soos in die slot verkondig. Die jaarritme soos in die Geserkalender beskryf, word buite werking gestel. Menslike berekening verval; blykbaar ook die 
berekening om te raap en skraap om soveel moontlik in die hande te kry - sodat selfs die Sabbat as 'n oorsaak van verliese gesien en daarom omgewens word (8:5). Die armes en verontregtes sal daarom tot hulle reg kom (vgl. ook Weippert, 1985:19-20). Dit gaan egter nie vir Amos om die armes self nie. Hier is nie 'n vervanging van die bevoorregtes deur die onbevoorregtes nie, maar 'n nuwe situasie vir die volk van God as 'n geheel. Sowel nasionale as "klasse"groeperings word deurbreek.

Vers 13-14 sluit by Amos se spraakgebruik aan deur die nadruk te lê op die mens en sy werk sodat die paradyssituasie op die agtergrond gestoot word (Weippert, 1985:20). Die verkondiging van die boek is in 'n hegte eenheid geïntegreer.

\section{Samevatting en gevolgtrekking}

Net so verrassend anders as wat die aankondiging van die dag van Jahwe deur Amos vir Israel was, net so verrassend anders is die aankondiging in die slot van die boek. Eersgenoemde bevat egter onverwagte en vernietigende straf; laasgenoemde onverwagte voorspoed en vrede vir Israel in die land waaruit hulle weggevoer is. Die redding sal nie siklies wees, 'n blote herhaling van die tyd van vroeër nie. Daar sal wel 'n tyd soos dié van Dawid kom, maar die beloofde ryk sal universeel wees en die nasies sal in die oorwinning deel (9:11-12). Verder sal dit 'n tyd van wonderbaarlike voorspoed en vrede wees (9:13-15). In hierdie opsig kom die boek as geheel ooreen met die lyn van lewewekkende optrede van God wat dwarsdeur die Ou Testament loop. Openbaringshistories gesien, loop die tyd telkens dood, maar God maak weer wonderbaarlik 'n nuwe begin daaruit. Hier in Amos is 'n situasie soos by die sondvloed: net so korrup en net so ingrypend vir die geskiedenis. Die uitkoms daaruit is die vrug van God se lewewekkende optrede en is geheel en al die gevolg van sy eie inisiatief en optrede, sonder enige verdienste van die kant van mense. Hy sorg dat die tyd voortgaan in vaste opeenvolging van seisoene en voorspoed.

Aan die kern van die saak lê die feit dat God almagtig en vrymagtig is en dat Hy 'n persoonlike God is vir wie dit om persoonlike verhoudings gaan. Hy sal die verhouding met Hom herstel. Dit sluit sy seën in die natuur asook die regte verhouding met die naaste in. Laasgenoemde word wel nie uitdruklik gestel nie, maar word veronderstel en is deel van 'n geïntegreerde benadering. Amos benadruk juis dat ware religie integrering impliseer, soos gawe én eis in die kwessie van verkiesing (3:2), spesifieke verbondsverhouding én universele doel (9:7), die dien van Jahwe én reg doen aan mense in die gewone lewe $(5: 4,15)$.

In die aankondiging van heil ondanks die aangekondigde ondergang gaan dit om ' $n$ heeltemal ander integrering as in Israel se tydsberekening. Hulle het seisoene bereken en probeer manipuleer aan die hand van die waarneming van sterre, gepaard met 'n kultus wat gestol was in 'n sikliese, mitologiese benadering van 
tyd en gebeurtenisse. Jahwe transendeer menslike begrip en manipulering. Hy transendeer tyd en stel nuwe omstandighede in vooruitsig, konkreet en in aansluiting by die verlede, maar met 'n nuwe kwaliteit.

Die slot vorm saam met die res 'n geïntegreerde eenheid en verkondig dat Jahwe alleen en persoonlik in volle beheer is van tyd en gebeurtenisse. 'n Sikliese, mitologiese benadering bring ondergang as gevolg van verontpersoonliking in die godsdiens, outomatiese sekerheid, vormgodsdiens en verontmensliking en veronregting in die samelewing. Alleen geloof in die persoonlike God wat beskik oor lewe en dood en oor die verloop van die seisoene, en dus van tyd, kan uitsig bring op die ware lewe van volheid en voorspoed.

Amos het dit teen Israel dat hulle godsdiens en daaglikse lewe uit mekaar haal en hy benadruk dat hulle dinge moet sien soos hulle in 'n groter verband geïntegreer is. Die slot plaas die seël daarop en integreer ondergang en lewe deur die lewewekkende optrede van Jahwe. Hy is die God wat integreer en tegelykertyd transendeer.

\section{Bibliografie}

BRINKMAN, J. 1992. The perception of space in the Old Testament. Kampen : Kok Pharos.

CHILDS, B.S. 1979. Introduction to the Old Testament as Scripture. London : SCM.

DEIST, F.E. \& LE ROUX, J.H. 1987. Revolution and reinterpretation. Cape Town : Tafelberg.

FIRTH, D.G. 1996. Promise as polemic: levels of meaning in Amos 9:11-15. Old Testament Essays, 9(3):372-382.

FRITZ, V. 1987. Die Fremdvölkersprüche des Amos. Vetus Testamentum, 37(1):26-38.

HELBERG, J.L. 1997. Goddelike onberekenbaarheid en menslike toerekenbaarheid in die boek Amos. In die Skriflig, 31(4):403-419.

HEYNS, Dalene. 1995. God and history in Deutero-Isaiah. Considering theology and time. Old Testament Essays, 8(3):340-355.

HEYNS, Dalene. 1997a. Space and time in Amos 7: reconcidering the third vision. Old Testament Essays, 10(1): 27-38.

HEYNS, Dalene. 1997b. Space and time in Amos 8: an ecological reading. Old Testament Essays, 10(2): 236-251.

HOLWERDA, B. 1971. Historia Revelationis Veteris Testamenti. Kampen : Kopiëerinrichting V.d. Berg.

JENNI, E. 1971. Jom Tag. (In Jenni, E. \& Westermann, C., Herausgbs. Theologisches Handwörterbuch zum Alten Testament. I. München : Kaiser. p. 707-726.)

JENNI, E. 1976. 'et Zeit. (In Jenni, E. und Westermann, C., Herausgbs. Theologisches Handwörterbuch zum Alten Testament. 2. München : Kaiser. p. 370-385.)

LEVENSON, J.D. 1985. Sinai and Zion: an entry into the Jewish Bible. Minneapolis : Winston Press.

OLIVIER, H. 1996. Putting the Holy Land on the map. Old Testament Essays, 9(2):249-260.

PREUSS, H.D. 1991. Theologie des Alten Testaments. I. Stuttgart : Kohlhammer.

SAEBO, M. 1980. Jwm. (In Botterweck, G.J. \& Ringgren, H., Herausgbs. Theologisches Wörterbuch zum Alten Testament. 3. Stuttgart : Kohlhammer. p. 580-586.) 
SNAITH, N.H. 1963. Time in the Old Testament. (In Bruce, F.F., ed. Promise and fulfilment. Essays presented to S.H. Hooke. Edinburgh : Clark. p. 175-186.)

TALMON, S. 1986. King, cult and calender in ancient Israel. Jerusalem : Magness Press, Hebrew University.

TSEVAT, M. 1982. jerûsalem / jerusalajim. (In Botterweck, G.J. \& Ringgren, H., Herausgbs. Theologisches Wörterbuch zum Alten Testament. 3. Stuttgart : Kohlhammer. p. 930939.)

VAN LEEUWEN, C. 1985. Amos. Nijkerk : Callenbach. (Prediking van het Oude Testament.)

VON RAD, G. 1962. Old Testament Theology. I. Edinburgh : Oliver \& Boyd.

VON RAD, G. 1978. "Day in the OT". (In Kittel, G., ed. Theological Dictionary of the New Testament. Grand Rapids : Eerdmans. p. 943-947.)

VRIEZEN, TH. C. 1963. Studies on the Psalms. Papers read at $6^{\text {th }}$ Meeting of Die O.T. Werkgemeenskap in Suid-Afrika at Potchefstroom, 1963. Potchefstroom : Pro Rege Pers. p. 5-17.

WEIPPERT, H. 1985. Amos: Seine Bilder und ihr Milieu. (In Weippert, H., Seybold, K. \& Weippert, M. Beiträge zur prophetischen Bildsprache in Israel und Assyrien. Friburg : Universitätsverlag. p. 1-29.)

WESTERMANN, C. 1974. Genesis. Neukirchen-Vluyn : Neukirchener Verlag. (Biblischer Kommentar Altes Testament.)

WESTERMANN, C. 1978. Theologie des Alten Testaments in Grundzügen. Göttingen : Vandenhoeck \& Ruprecht. (Grundrissen zum Alten Testament.) 